\title{
Syntheses of Tetrasulfonylcalix[4]biscrown-6 and Crystal Structures
}

\author{
Jac Kwang Lee, ${ }^{\dagger}$ Wonbo Sim, ${ }^{\phi}$ Sung Kuk Kim, Ju Han Bok, Mi S. Lim, \\ Soon W. Lee, ${ }^{\mp}$ Nam Sook Cho, ${ }^{*}$ and Jong Seung Kim ${ }^{*}$ \\ Deparment of Chemistry, Dankook University; Seoul 140-7/4. Korea \\ ${ }^{\dagger}$ Department of Chemistry, Konyang University; Nonsan 320-711. Korea

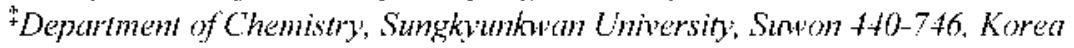 \\ ${ }^{\$}$ Depatment of Chemistr, Chungnam National University, Daejeon 305-764, Korea \\ Received November 14.2003
}

Key Words : Calixarenes, Thiacalixarenes, Crystal structures, Crown ethers

Since Kumakai et al. 'reported viable synthetic routes on $p$-tent-butylthiacalixarenes in 1997, this class of macrocyclic ligand has attracted considerable interest as an alternative to 'classic" calixarenes ${ }^{2}$ by providing sites for functionalization not only on the aromatic rings but also on the bridging sulfur atoms. Thiacalixarenes possess additional coordination sites and the cavity dimensions are increased compared with analogous calixarenes. Unlike calix[4]arenes, thiacalix[4]arenes show affinity for transition metal ions because the sulfur atoms in the calixarene framework take part in the metal ion complexation." For this concern, syntheses of several 1,3-thiacalix[4]biscrown derivatives, the first representatives of crown ether-bridged compounds in the thiacalixarene series were reported. ${ }^{+}$Investigation of their complexing abilities towards alkali metal cations $\left(\mathrm{Na}^{-}, \mathrm{K}^{-}\right.$. $\mathrm{Rb}^{+}$, and $\mathrm{Cs}^{-}$) showed lower extraction efficiencies than those for related 1,3-calix[4]biscrown-5 and crown-6. This behavior was attributed to a larger (about $0.5 \AA$ ) thiacalix[4] arene cavity as determined from X-ray crystal diffraction. ${ }^{5}$ Molecular modeling indicated that the $\mathrm{Cs}^{+}$ion is located close to the thiacalix[4]arene cavity, but does not interact with the crown ether unit leading to less efficient binding. ${ }^{5}$

Previously we reported on synthesis and metal ion oscillation behavior of a series of thiacalix [4]monocrowns and thiacalix[4]biscrowns. ${ }^{5 \mathrm{th}}$ The cesium ion was more rapidly oscillated in thiacalix[4]crowns than in the conventional calix[4]biscrowns because the former has weaker electrostatic interactions of the polyether ring oxygen atoms with the metal ions and diminished p-metal ion interactions between the metal ions and the aromatic rings of the thiacalix[4]crowns. With keeping the metal ion binding behavior of the thiacalixcrown compounds in mind, we tried to prepare a tetrasulfonylcalix[4]crown by oxidation of the thiacalix[4]crown molecule.

Our synthesis began with para-tert-butylphenol which was cyclized with sulfur molecule $\left(\mathrm{S}_{8}\right)$ to give a para-tertbutylthiacalix[4]arene (1)" as shown in Scheme 1. Dealkylation using $\mathrm{AlCl}_{3}$ in phenol provided a thiacalix[4]arene (2) in moderate yield. Subsequently, 1,3-alternate thiacalix[4]biscrown-6 (3) was synthesized from the reaction of the thiacalix [4]arene (2) with ditosylate of tetraethyleneglycol in the presence of $\mathrm{K}_{2} \mathrm{CO}_{3}{ }^{5}$ Oxidation of 3 with 5 equiv of
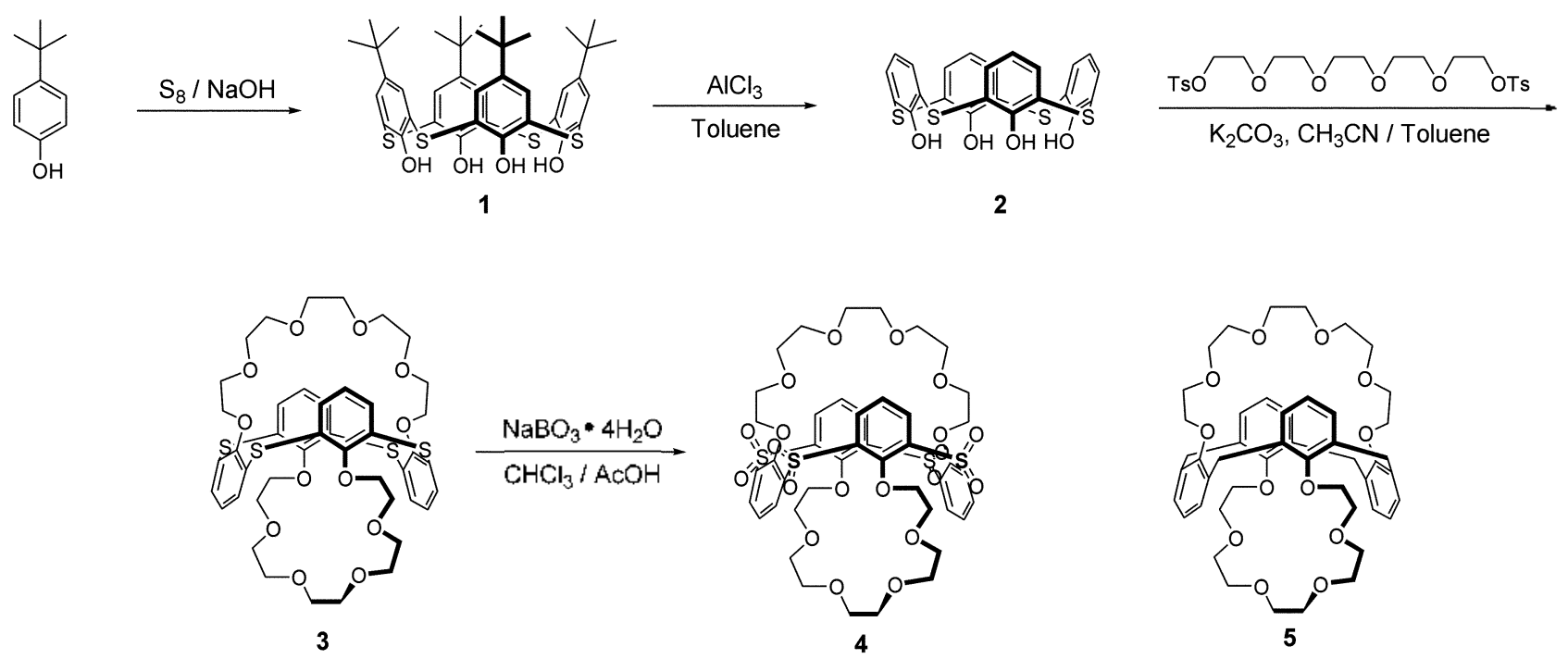

Scheme 1. Synthesis of tetrasulfonylcalix [4]-bis-crown-6.

"Corresponding Author. e-mail: jongskim (y)dankook.ac.kr 
$\mathrm{NaBO}_{3} / \mathrm{AcOH}$ produced tetrasulfonylcalix[4]biscrown-6 (4) in $33 \%$ yield. The conformation of $\mathbf{3}$ and $\mathbf{4}$ were confirmed by X-ray diffraction (Figures I and 2).

Both 3 and $\mathbf{4}$ were crystallized in the tetragonal and their space group are $I_{1}$ and $P 4_{2} 2_{1} 2$, respectively. The thiacalix[4]arene platform in both $\mathrm{A}$ and $\mathrm{B}$ molecules is in the 1,3alternate conformation. Except for the sulfonyl oxygen atoms. both compounds are isostructural and have a pseudo 4-fold rotationre-flection $\left(S_{i}\right)$ axis. Consistent with this symmetry, the facing benzene rings are relatively parallel to each other and the adjacent benzene rings lie above and below the plane defined by the four sulfur atoms. The pseudo $S_{i}$ symmetry also reasonably depicts the overall perpendicular orientation of two cyclic ether moieties above and below the sulfur planes. Regarding the distance between two facing benzenes. which is quite related to the $\pi$-cesium complexation, tetra-sulfonll-thiacalix [4]biscrown-6 (4) was of shorter distance with $4.088 \AA$ than the thiacalix[4]biscrown-6 (3) $(5.023 \AA)$ as shown in Figure 1 and 2.

Extractabilities $(E \%)$ of $\mathbf{3}$ and $\mathbf{4}$ toward $\mathrm{Na}^{-}, \mathrm{K}^{+}, \mathrm{Rb}^{+}, \mathrm{Cs}^{-}$, $\mathrm{NH}_{4}{ }^{-}, \mathrm{Ag}^{-}, \mathrm{Sr}^{2+}, \mathrm{Ba}^{2-}$, and $\mathrm{Pb}^{2+}$ were determined by twophase picrate extraction and the results are summarized in Table 1. Both compounds gave lower extractabilities than the conventional 1,3-calix[4]biscrowns. ${ }^{6}$ For tested cations, compound 3 shows a cesium ion selectivity, probably because the crown- 6 ring and two aromatic benzene rings ( $\pi$-metal complexation) participated in the metal ion complexation. For $\mathbf{4}$, however, the binding ability for cesium ion diminished. Lower extractability of tetrasulfonyl-calix[4]biscrown-6 toward $\mathrm{Cs}^{-}$ion is due to the fact that a distance between two facing benzene rings of the tetrasulfonylcalix[4]biscrown-6 (C4-2 to C4-8 $=4.088 \AA$ ) was shorter than that of thiacalix[4]biscrown- $6\langle\mathrm{C} 3$ to $\mathrm{C} 3-2=$

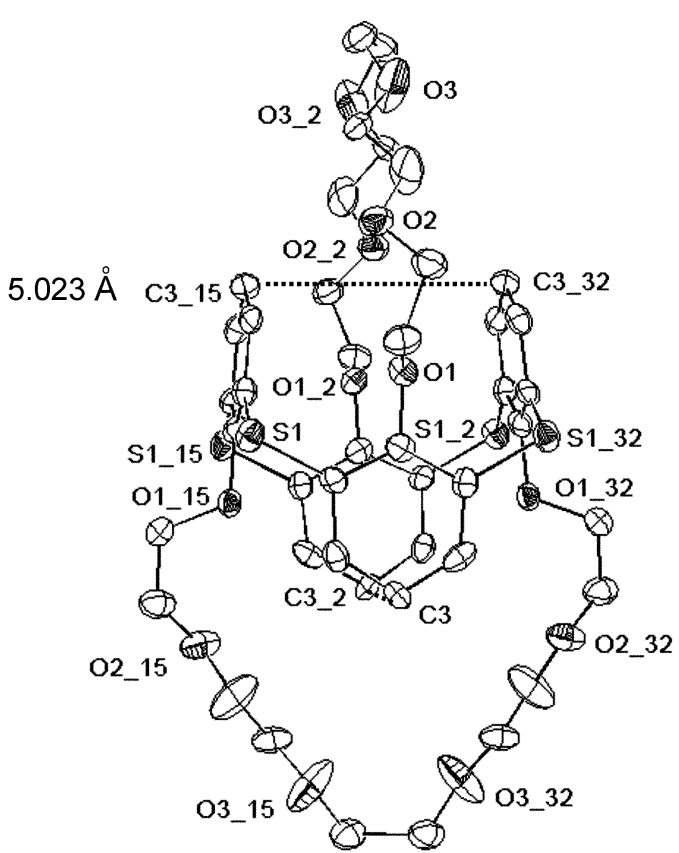

Figure 1. ORILP drawing of 3 with $50 \%$ probability thermal cllipsoids.

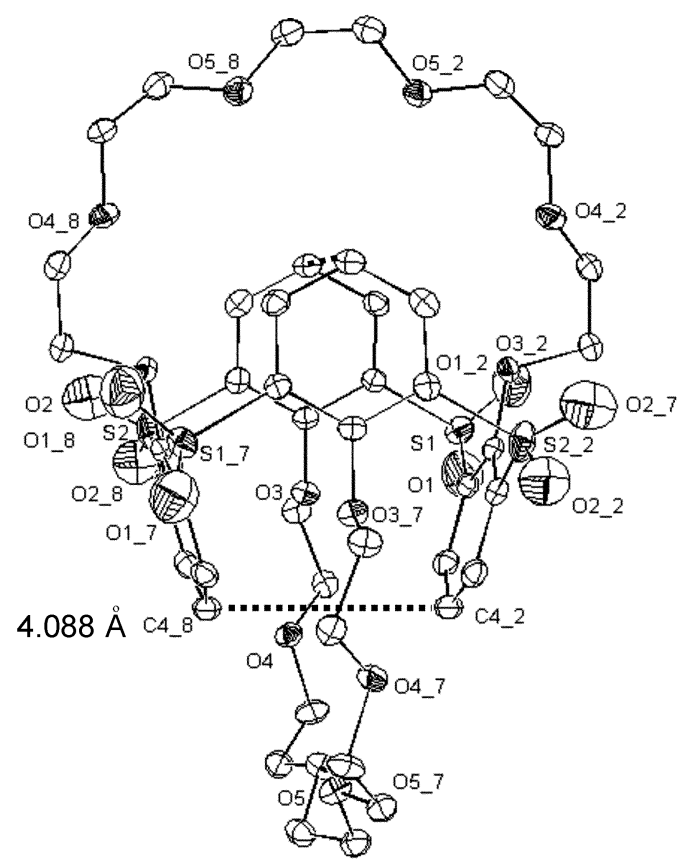

Figure 2. ORILP drawing of 4 with $50 \%$ probability thermal sllipsoids.

Table 1. Extractability ( $E \%$ ) of cation picrates by ligands

\begin{tabular}{|c|c|c|c|c|c|c|c|c|c|}
\hline & \multicolumn{9}{|c|}{ l:xtraclability $(\%)$} \\
\hline Ligand & $\mathrm{Na}$ & $\mathrm{K}^{\prime}$ & $\mathrm{Rb}$ & $\mathrm{Cs}^{+}$ & $\mathrm{NH}_{4}$ & $\Delta g$ & $\mathrm{Sr}^{2}$ & $\mathrm{Ba}^{2}$ & $\mathrm{~Pb}^{2-}$ \\
\hline 3 & 0 & 0 & 8.5 & 27.2 & 1 & 0.9 & 0.7 & 3.9 & 0 \\
\hline 4 & 1.8 & 0.8 & 0 & 1.5 & 1.2 & 2 & 1.2 & 1.3 & 0 \\
\hline
\end{tabular}

$5.023 \AA$ ) to give an insufficient space to the $\pi-\mathrm{Cs}^{-}$ion complexation (see Figures 1 and 2).

\section{Experimental Section}

Synthesis. Compounds 1-3 were prepared following procedures reported in literature.

$\mathbf{2 , 8 , 1 4 , 2 0}$-Tetrasulfonylcalix $|\mathbf{4}|$-bis-crown-6 (4). A solution of $(0.50 \mathrm{~g}, 0.55 \mathrm{mmol})$ of thiacalix[4]biscrown-6 (3) and sodium perborate tetrahydrate $(0.42 \mathrm{~g} .2 .72 \mathrm{mmol})$ in chloroform $(50 \mathrm{~mL})$ and acetic acid $(80 \mathrm{~mL})$ was stirred at room temperature for $10 \mathrm{~h}$. To the reaction solution were added $100 \mathrm{~mL}$ of $\mathrm{CHCl}_{3}$ and $100 \mathrm{~mL}$ of $10 \%$ aqueous $\mathrm{NaHCO}_{3}$ solution. The organic layer was separated and dried over $\mathrm{MgSO}_{4}$. Removal of the organic solvent in vacuo gave a white solid. Purification by column chromatography using ethyl acetate/hexane $(1: 1)$ as eluents gave 4 as a white solid. Yield $33 \%$. Mp $289.4-293.5^{\circ} \mathrm{C}$ : IR ( $\mathrm{KBr}$ pellet, $\mathrm{cm}^{-1}$ ): $2872,1567,1436,1359,1306,1235,1135,1050$; 'H NMR $(200 \mathrm{MHz}, \mathrm{CDCl}): \delta 8.16-7.15\left(\mathrm{~m}, 8 \mathrm{H}, \mathrm{Ar}-H_{m} ; 4 \mathrm{H}, \mathrm{Ar}-H_{p}\right)$, 4.85-3.81 (m, $\left.40 \mathrm{H}_{1}-\mathrm{OCH}_{2} \mathrm{CH}_{2} \mathrm{O}-\right)_{2} \mathrm{FAB} \mathrm{MS}, m /=\left(\mathrm{M}^{\prime}\right)$ caled 1029.14, found: 1029.15 .

Two-phase extraction. All solvents and inorganic compounds were purchased from Aldrich Chemical and Prolabo. Metal picrates were prepared by reaction of picric acid with the appropriate metal carbonate. Liquid-liquid 
Table 2. Crystallographic Data and Structure Retinement Parameters for $\mathbf{3}$ and 4

\begin{tabular}{|c|c|c|}
\hline Parameter & 3 & 4 \\
\hline Empirical formula & $\mathrm{C}_{4\lrcorner} \mathrm{H}_{3} \leqslant \mathrm{O}_{1} \leq \mathrm{S}_{4}$ & $\mathrm{C}_{44} \mathrm{H}_{32} \mathrm{O}_{20} \mathrm{~S}_{4}$ \\
\hline Formula weight & 901.1 & 1029.1 \\
\hline Temperature $(\mathrm{K})$ & $293(2)$ & $295(2)$ \\
\hline Crystal system & Tetragonal & Tetragonal \\
\hline space group & $\mathrm{I} 41 / \mathrm{acd}$ & $P 4_{2} 2,2$ \\
\hline \multirow[t]{3}{*}{ Unit cell dimensions } & $\mathrm{a}=14.817 \AA \alpha=90^{\circ}$ & $a=12.786(2) \AA$ \\
\hline & $\mathrm{b}=14.817 \AA \beta=90^{\circ}$ & $c=14.155(2) \AA$ \\
\hline & $c=40.848 \AA \gamma=90^{\circ}$ & \\
\hline Volume & $8968(4) \AA$ & $2314.1(5) \AA$ \\
\hline$Z$ & 8 & 2 \\
\hline Density (calculated) & $1.335 \mathrm{~g} / \mathrm{cm}^{3}$ & $1.477 \mathrm{~g} / \mathrm{cm}^{3}$ \\
\hline Absorption coefticient & $0.273 \mathrm{~mm}^{-1}$ & $0.287 \mathrm{~mm}^{-1}$ \\
\hline$F(000)$ & 3808 & 1080 \\
\hline Crystal size & $0.5 \times 0.1 \times 0.5 \mathrm{~mm}$ & $0.50 \times 0.44 \times 0.40 \mathrm{~mm}$ \\
\hline $2 \theta$ data collection & 11.709 to $18.490^{\circ}$ & 3.5 to $50^{\circ}$ \\
\hline Independent reflections & 1977 & 1204 \\
\hline Goodness-of-tit on $\mathrm{F}^{2}$ & 1.188 & 1.067 \\
\hline $\mathrm{R}$ indices (all data) & $\mathrm{RI}=0.1518 w \mathrm{R} 2=0.4448$ & $\mathrm{Rl}=0.0815 \mathrm{wR} 2=0.1844$ \\
\hline Largest diff. peak and hole & 0.535 and $-0.853 \mathrm{e} . A^{-3}$ & 0.237 and $-0.395 \mathrm{e} \AA^{-3}$ \\
\hline
\end{tabular}

solvent extraction experiments were performed by contacting an aqueous solution $(2.0 \mathrm{~mL})$ containing the metal picrate $(0.20 \mathrm{mM})$ and a chloroform solution $(2.0 \mathrm{~mL})$ of the ligand $(0.10 \mathrm{mM})$ with shaking for $30 \mathrm{~min}$ at $25^{\circ} \mathrm{C}$. The concentration of picrate anion extracted from the aqueous phase into the organic layer was deternined by UV spectrophotometry $\left(\lambda_{\max }=373 \mathrm{~nm}\right.$ ). Three independent experiments were carried out for each combination of ligand and metal picrate.

Solid-state determination. Both single crystals of $\mathbf{3}$ and 4 were obtained by slow evaporation of $\mathrm{CH}_{3} \mathrm{OH} / \mathrm{CH}_{2} \mathrm{Cl}_{2}$ (1:9). All X-ray data were collected with the use of a Siemens $\mathrm{P} 4$ diffractometer equipped with a Mo X-ray tube and a graphite monochromator. The orientation matrix and unit-cell parameters were determined by the least-squares analyses of the setting angles of 28 reflections in the range $10.0^{\circ}<2 \theta<25.0^{\circ}$. Three check-reflections were measured every 100 reflections throughout data collection. Intensity data were empirically corrected for absorption with $\psi$-scan data. All calculations were carried out with the use of SHELXTL programs. ${ }^{\S}$

Acknowledgment. This present research was conducted by the research fund of Dankook University in 2003.

\section{References}

1. Kunagai. H.: Hasegawa. M.: Myanari. S.: Sugawa, Y: Sato. Y.: Hori. T.: Ueda. S.: Kaniyama. H.: Miyano. S. Tetrahedron Lett.
$1997.38,3971$

2. (a) Gutsche. C. D. Calixarnes, Honographs in Supramolecular Chemistry, Stoddart, J. F., Ed.; Roval Society of Chemistry: Cambridge. U. K.. 1989: Vol. 1. (b) Calixanenes A Tersatile Class of Hachocycic Componds: Vicens. I. Böhmer. V.. Eds.: Kluwer: Dordrecht. 1991.

3. Iki. N.: Kabuto. C.: Fukushima T.; Kumagai, H; Takeya, H.; Miyanari. S.; Mivashi, T,; Myano, S. Tetrahedron Lett. 2000. 56. 1437.

4. (a) Casnati. A.: Unngaro. R.: Asfari. Z.: Vicens. J. In Calixarenes 2001: Asfari. Z: Böhmer. V: Harrowtield. J.: Vicens. I.. Eds.: Kluwer Academic Publishers: Dordrecht. Holland. 2001: pp 365384. (b) Iki. N.: Morohashi. N.: Narumi. F.; Myano. S. Bull. Chem. Soc. Jpu. 1998, 71, 1597. (c) Iki. N.: Kumakai. H.; Morohashi, N.: Ejima. K.; Hasegawa. M.; Miyanar, S.: Miyano, S. Tetrahedron Lett. 1998. 39.7559. (d) Hosseini. W. In Calixarenes 2001: Astari. Z.: Böltmer. V.: Harrowfield. J.: Vicens. J.. Eds.: Kluwer Academic Publishers: Dordrecht. Holland. 2001.

5. (a) Lamare. V: Dozol. J.-F.; Thuéry. P. Nierlich. M: Astäri, Z: Vicens, J. J. Chem. Soc. Perhin Trans. 22001 , 1920. (b) Lee, J. K.: Kim. S. K; Bartsch. R. A.; Vicens. J; Myano, S.: Kim. J. S. $J$. Org. Chem. 2003. 68. 6720 (c) Kiml. J. S.: Thuery. P.: Nierlich. M.: Rim. I. A.: Yang. S. H.: Lee. J. K.: Vicens. T. Bull. Kot: Chent. Soc. 2001. 22(3). 321. (d) Kiml. I. S.: Yu. S. H.: Cho. M. H.; Shon. O. J.: Rim. J. A.; Yang. S. H.: Lee, J. K : Lee. S. J. Bull. Kowan Chem. Soc. 2001. 22(5), 519. (e) Sim. W. Lee. J. Y: Kwon. J.: Kim, M. J; Kim, J. S. Bull. Kor: Chem. Soc. $2002,23$. 879 .

6. Bartsch. R. A.: Yang. I. W: Teon. E. G.: Walkowiak. W: Charewicz. W. A. J. Coord Chen. 1992. 27.75.

7. Iki. N.: Mivano, S. J. Incl Phen. Hacho Chent $2001,41,99$.

8. Bruker. SHEL1TL: Structure Determination Software Programs. Bruker Analytical X-ray Instruments Inc.: Madison, Wisconsin. USA. 1997 